\title{
APPLICATION OF WORK-BASED LEARNING MODEL IN TECHNICAL AND VOCATIONAL EDUCATION: A SYSTEMATIC REVIEW
}

\author{
Rabiu Haruna ${ }^{1,2}$ and Yusri bin Kamin ${ }^{1^{*}}$ \\ ${ }^{1}$ Department of Technical and Engineering Education, School of Education, Universiti Teknologi Malaysia, Johor Bahru \\ ${ }^{2}$ Department of Electrical and Electronic Technology Education, SOSE (Technical), Federal College of Education (Technical) Bichi, Kano, Nigeria \\ *Corresponding Author Email: p-yusri@utm.my
}

This is an open access article distributed under the Creative Commons Attribution License, which permits unrestricted use, distribution, and reproduction in any medium, provided the original work is properly cited

\section{ARTICLE DETAILS}

\section{Article History:}

Received 01 April 2019 Accepted 30 May 2019 Available online 14 June 2019

\section{ABSTRACT}

Technical and Vocational Education and Training (TVET) is envisioned to prepare a workforce which has knowledge of behaviour and skills that could enable them in securing and maintaining their job effectively. Thus, in carrying out the task, two main elements are involved; institution and workplaces. Students receive training in the theory aspect from school and practice in industry. Therefore, relationship between these two elements is essential for the attainment of goals TVET. This study aims to provide a systematic review of published researches on the current practice of Work-based Learning in TVET and to assess the major challenges that affect the relationship between school and workplace with a view to make recommendations for the best practice in future application of WBL in TVET. To achieve this aims, papers were selected in April 2018 with search terms "Work-Based Learning" "Conceptual Model of WBL" "WBL in TVET" and "Implementation of WBL in TVET" from five databases: Scopus, PsycINFO, Springer, Google Scholar, and ScienceDirect.16 research based article were evaluated published from 2000 to 2018. Findings revealed the extent of the implementation of WBL in TVET in tertiary institutions including universities is low. Emphasis was given to some aspects such as Student Industrial Work Experience Scheme (SIWES) leaving other aspects unexploited. These unexploited aspects include cooperative work experience, job shadowing, youth apprenticeship programme, internships among others etc. Factors affecting the implementation of WBL in TVET identified in the reviewed researchers were curriculum defects, poor policy framework, inadequate trained manpower to supervise the proper implementation and lack of WBL learning implementation framework in institution of learning. The findings add to the growing empirical evidence regarding the positive impact of WBL in TVET. Policy makers, educators, and the public can contribute to development of TVET by supporting the incorporation of WBL into standard TVET practices.

\section{KEYWORDS}

Work-based Learning, Systematic Review, Technical and Vocational Education and Training

\section{INTRODUCTION}

Technical and Vocational Education and Training (TVET) is envisioned to prepare a workforce which has knowledge of behavior and skills that could enable them in securing and maintaining their job effectively. Industrialized nations consider it as a vital element in national development plans due to its significant impact on the economic growth, industrial development and productivity of a country [1]. According to research, this educational field enables an individual to have a quality job in a specific career as semi or fully skilled worker [2]. Furthermore, it provides an individual with fundamental cognitive, plus practical skills required for entering in the labor market.

Many employers feel that young people leave the education system lacking the practical skills they need for the labour market. Once in employment, people need to continue learning in order to keep up with the changing nature of their jobs. Thus, learning is no longer considered a preparatory stage prior to employment, but is increasingly seen as a constituent part of working life. These considerations, together with other factors, have led to greater recognition in academic debate of the importance of the learning processes that take place in the workplace. Conventional theories of learning and human capital have been increasingly challenged by the development of 'situated approaches to learning'. In simple terms, situated learning is learning that takes place in the same context in which it is applied. Lave and Brown argue that most classroom-based learning involves the acquisition of abstract knowledge out of context, while learning needs to be 'embedded within activity, context and culture'.

Indeed, the traditional view of learning as acquisition-a view that still predominates in many education and training systems and many formal learning contexts-is based on the assumption that knowledge exists independently of the learner but can be transmitted to the learner. By contrast, the learning as participation approach (to which WBL is related) considers that learning is social, composed of a variety of components, and comes from experiencing and participating in daily life, which includes the relations, content and context of work [3]. Indeed, social interaction is a critical component of situated learning because learners become involved in a community-of-practice that embodies certain beliefs and behaviours to be acquired.

A previous researcher state that when Work-based learning (WBL) program is applied in a workplace context, it genuinely encompasses real 
experiences once the transformation of theory into practice has been taken place [4]. WBL offers plentiful opportunities for learners to acquire diversified skills with the assurance of harmonious relationship between school and world of work. It attempts to reduce the gap between theory and practice so that, learning can be meaningful. It creates a formidable connection between classroom instruction, the world of work and failure career opportunities because, school-based learning as well as professional work training do not guarantee a suitable learning that can satisfy the required qualification for the world of work.

\section{LITERATURE REVIEW}

\subsection{What is Work-based learning (WBL)?}

There is no single definition of what Work-based learning (WBL) entails beyond the notion that it implies two characteristics: learning in a work context and learning through practice. A distinction is typically made, however, between learning for work (e.g. during a work placement as part of a TVET curricula) and learning at work (e.g. in-house company training). WBL is an experiential learning programme which uses work environment as a crucial element of the curriculum [5]. WBL provides learners with structured learning experiences by collaborating with employers of the labor and school. A researcher states that WBL offers a working experience that makes students learn about how they can apply the learned skills in an actual working environment [6]. It's literally an effort to enlarge the exposure of a classroom by including the community as a learning resource. As a partnership program, the WBL program has to be designed to support in producing the highly technical skills in the workplace; therefore, the educational program must be adaptable, flexible and relevant to workplace training.

A researcher further points out that WBL 'differs from conventional training in that it involves deep and conscious reflection on actual experience at the workplace'. In addition to the acquisition of specific skills and competences, the learner's ability to developing meta-competence and learning-to-learn skills is becoming even more critical than learning specific tasks. This view is confirmed by a researcher, who state that parallel to the learners' vertical development WBL also supports their horizontal development.

WBL holds career development as one of its elements that provides an exposure of different work settings to learners which then helps them to make appropriate decisions for their future career choices. Furthermore, WBL is categorized into cooperative work, field trips, job shadowing, school-based enterprise, entrepreneur, internship, and youth apprenticeship [7].

\section{OBJECTIVE}

This study aims to provide a systematic review of published researches on the current practice of Work-based Learning in TVET and to assess the major challenges that affect the relationship between school and workplace with a view to make recommendations for the best practice in future application of WBL in TVET.

\section{METHODOLOGY}

To achieve this aim, papers were selected in April 2018 with search terms "Work-Based Learning" "Conceptual Model of WBL" "WBL in TVET" and "Implementation of WBL in TVET" from five databases: Scopus, PsycINFO, Springer, Wiley Online Library and ScienceDirect. Other materials of relevant studies were searched using Google Scholar. During the initial phase, there was no limitation on searching relevant studies, all research papers, concept papers, conference and other technical or government reports. Hence, the search found a total of 167 papers which stated about WBL in TVET. In the second phase the number of articles were reduced to 18 articles that, satisfied the inclusion criteria i.e (1) The selected articles were limited to those published from 2000 to 2018 (2) The studies conducted with TVET students/trainees at any level of the formal TVET training (3) Empirical, WBL studies with technical and vocational education exposure reported on quantitative data.

\section{FINDINGS/RESULT}

The results of this review depict the main themes that are relevant for Work-Based Learning implementation, effectiveness and challenges faces in the process of integrating it in learning of knowledge, skills and attitudes in schools and workplaces.

These main themes are: in terms of WBL implementation and effectiveness, 10 studies show that, WBL impacts include enhancing students' employability skills, attitude and interpersonal relationship. In relation to second theme of challenges faces in the process of integrating it in learning of knowledge, skills and attitudes in schools and workplaces, 8 studies show that, constraints to the implementation of WBL includes poor teacher quality, poor policy frame-work, lack of WBL implementation framework and curricular provision/defects. The 18 articles are clustered per two main themes in table 1 and table 2 .

The findings for each of these two main themes are described below. In the description of all themes, the researcher clearly focuses on the question what the literature in each theme contribute in understanding of WBL implementation and effectiveness in students learning in school and the workplace. Due to the selection criteria in this review the descriptions of the themes are based on 10 and 8 articles as interpreted respectively.

Table 1: Analysis on Impacts of Work-based Learning in TVET

\begin{tabular}{cccc}
\hline Studies & Employability Skills & Attitude & Interpersonal Relationship \\
\hline$[8]$ & $\sqrt{ }$ & $\sqrt{ }$ & \\
{$[9]$} & $\sqrt{ }$ & $\sqrt{ }$ & $\sqrt{ }$ \\
{$[10]$} & $\sqrt{ }$ & $\sqrt{ }$ & $\sqrt{ }$ \\
{$[11]$} & $\sqrt{ }$ & & $\sqrt{ }$ \\
{$[12]$} & $\sqrt{ }$ & $\sqrt{ }$ & \\
{$[13]$} & $\sqrt{ }$ & $\sqrt{ }$ & \\
Dupree, 2012 & $\sqrt{ }$ & & \\
{$[14]$} &
\end{tabular}

\subsection{Work-Based Learning implementation and effectiveness}

\subsubsection{Employability Skills}

Eight empirical studies WBL in Vocational education were selected: All the 8 studies show that, work-based learning is beneficial to students in terms of employability skills within the context of their training in both schools and workplace. A researcher shows that, WBL had an impact on students' skills and also believed that, it increases students' knowledge of the qualification and skills required by employer. Similarly, another researcher revealed that, WBL contribute to students' learning experiences both in terms of subject-specific knowledge and skills.

\subsubsection{Attitude}

All the selected studies show that, work-based learning enhances students' attitude towards school-to-work. The attitude will make the acquisition of employability skills more easily by the students thereby satisfying industry requirements. A previous study revealed that, teachers believed that, WBL instilled in students a positive attitude toward schoolto-work and this will make the implementation of School-based and workbased activities more easily by the classroom teachers and industriesbased supervisors. Similarly, he shows that, proved extremely useful in developing their attitude towards work and acceptance of responsibility. 


\subsubsection{Interpersonal Relationship}

The selected studies indicate that, work-based learning enhances interpersonal relationships among students, teachers and industry-based supervisors. Example, Moise, et al. (2013) revealed that, WBL contribute to students' learning experiences both in terms of subject-specific knowledge and skills, and in developing their interpersonal, intrapersonal and intercultural skills.

Table 2: Analysis on Constraints of Implementing Work-based Learning in TVET

\begin{tabular}{ccccc}
\hline Studies & $\begin{array}{c}\text { Poor Teacher } \\
\text { Quality }\end{array}$ & $\begin{array}{c}\text { Poor Policy } \\
\text { Frame-work }\end{array}$ & $\begin{array}{c}\text { WBL Implementation } \\
\text { Framework }\end{array}$ & $\begin{array}{c}\text { Curricular } \\
\text { Provision/Defects, }\end{array}$ \\
\hline$[15]$ & $\sqrt{ }$ & $\sqrt{ }$ & $\sqrt{ }$ & $\sqrt{ }$ \\
{$[5]$} & & $\sqrt{ }$ & $\sqrt{ }$ & $\sqrt{ }$ \\
{$[16]$} & & $\sqrt{ }$ & $\sqrt{ }$ & $\sqrt{ }$ \\
{$[17]$} & $\sqrt{ }$ & $\sqrt{ }$ & $\sqrt{ }$ & $\sqrt{ }$ \\
Anohina-Naumeca\&Sitikovs, 2012 & & $\sqrt{ }$ & $\sqrt{ }$ \\
{$[18]$} & $\sqrt{19]}$ & & $\sqrt{ }$ & $\sqrt{ }$ \\
{$[14]$} & & & $\sqrt{ }$ & $\sqrt{ }$ \\
\hline
\end{tabular}

\subsection{Constraints of Implementing Work-based Learning in TVET}

Result of the review in respect of the challenges faces in the process of integrating it in learning of knowledge, skills and attitudes in schools and workplaces. The sub-themes are described below as presented in table 2 above.

\subsubsection{Poor Teacher Quality}

At least three of the selected articles in their findings identified poor quality teaching resources as one of the implementing constraints to work-based learning in TVET. A study showed that work integrated learning is implemented to low extent by the universities, and the implementation is constrained by many factors such as poor teacher quality. Similarly, another researcher arising from his findings asserted that research regarding WBL students' perceptions about their worksite mentor/supervisor abilities to teach the skills students need to learn should be conducted.

\subsubsection{Poor Policy Framework}

The reviewed studies brought the issue of poor policy framework as an obstacle to the effective implementation of WBL in TVET. A previous study showed that, the factors responsible for poor implementation of WBL in TVET were indicated to include poor policy framework and inexperience on the part of administrators of TVET programmes. In another study, WBL is implemented to low extent by the universities, and the implementation is constrained by many factors such as lack of policy and for WBL experiences and activities. This constraint shows that, policy framework should be provided and students to be provided with work-based learning experiences at the worksite equivalent or superior to learning in a classroom setting.

\subsubsection{WBL Implementation Framework}

All the selected studies provide evidences of lack of WBL implementation framework in institutions. Example, findings of a researcher indicated that, in the implementation of WBL institutions emphasised on the Student Industrial Work Experience Scheme only leaving other key components virtually untapped. Such other strategies identified by the studies included: job shadowing, cooperative work experience Programme, youth apprenticeship programme, school-based enterprises and internships. Causes responsible for this anomalous situation were indicated to include inexperience on the part of administrators of TVET programmes. Ignoring these important components of WBL will affect the validity and proper implementation of WBL programmes in TVET.

\subsubsection{Curricular Provision/Defects}

Seven empirical studies on integration of WBL in vocational training schools and workplaces were selected in this review. These empirical studies show that, inadequacy of the curricular affect the proper implementation of the WBL experiences in institutions and workplaces. The findings of a study showed that work integrated learning is implemented to low extent by the universities, and the implementation is constrained by many factors such as poor teacher quality, lack of policy and curriculum provisions for work integrated learning experiences and activities. Similarly, finding of another study indicated among factors responsible for the low implementation of WBL includes curricular defects in the TVET programmes. As part of the curricular defects, a researcher concluded that, school-based WBL activities were more easily implemented by the classroom teachers surveyed; career-related and work-based activities were more difficult to integrate into the curriculum.

\section{DISCUSSION}

This study reviewed some empirical studies on the implementation of Work-Based Learning, issues regarding to the effectiveness and challenges were also considered. An insight on the problem was adequately obtained from the literature.

In terms of WBL implementation and effectiveness, 8 studies show that, there is poor implementation of WBL. However, WBL impacts positively in enhancing students' employability skills, attitude and interpersonal relationship. Out of the many components of WBL only few were seemed to be implemented leaving key components untapped. Even the ones utilized were moderately implemented while eleven of them are lowly implemented with none of them highly implemented. Thus, only very few (mostly traditional ones) forms of work-based learning are implemented in developing country including Nigeria. This can further lead credence to the statement of a researcher that, lack of employability skills in most of Nigerian graduates particularly TVET graduates could be as a result of poor implementation of WBL, resulting from poor collaboration between institutions and industries. Though most of the studies revealed that, students' employability is enhanced but it seems to contradict the revelation of low implementation of WBL, since these contradictions cause difficulties in combining students' acquisition with practice.

In relation to second theme of challenges faces in the process of integrating it in learning of knowledge, skills and attitudes in schools and workplaces, 8 studies show that, constraints to the implementation of WBL includes poor teacher quality, poor policy frame-work, lack of WBL implementation framework and curricular provision/defects. These indicators show that, attainment of TVET objectives can be challenging with these constraints. These further show s that, that there are many indicators of failure in Technical, Vocational Education and Training (TVET) and are not getting the needed attention [20]. The identify problems can be addressed with a workable policy and implementation framework, enriched curricular and adequately trained personals. The TVET suffer neglect and abysmal poor funding. The poor curriculum content and policies of TVET in developing countries especially, Nigeria are the problems of program implementation by TVET institutions.

\section{CONCLUSION}

The review revealed an interesting trend in WBL implementation in the areas of its impacts, implementation status and constraints to the successful implementation. Key WBL components were ignored in the implementation i.e, job shadowing Cooperative education, Youth apprenticeship and internships e.t.c these can affect the validity of the implementation of WBL. Generally, the results of this review confirm that, WBL is beneficial to students and attainment of the goal of TVET, however, the several obstacles to the proper implementation of the WBL contradicts the effectiveness of the WBL in TVET due to the several identified 
shortcomings. In spite of the volume of literature reviewed in this study, existing overviews of the field do not provide high quality evidence with which to provide robust answers to questions about the effectiveness of WBL. Therefore, this conclusion can be a starting point for discussing and guiding TVET practitioners on the implementation inadequacy and the need to provide implementation framework for the attainment of the goals and objectives of TVET, thus more studies needs to be conducted in this direction.

\section{REFERENCES}

[1] Dike, V.E. 2009. Addressing youth unemployment and poverty in Nigeria: A call for action, not rhetoric. Journal of sustainable Development in Africa, 11(3), 129-151.

[2] Afeti, G. 2009. Technical and vocational education and training for industrialization. Paper presented at the African Research and Resource Forum. Retrieved January.

[3] Sfard, A. 1998. On two metaphors for learning and the dangers of choosing just one. Educational Researcher, 27, 4-13.

[4] Kamin, Y.B., Latib, A.A., Amin, N.F., Saud, M.S., Ahmad, A. 2018. WorkBased Learning: Employer Perspective Towards the Automotive Industry. Advanced Science Letters, 24(4), 2518-2521.

[5] Amadi, U.P.N. 2013. Appraising work-based learning experiences of technical vocational (teacher) educational and training (TVET) PROGRAMMES IN Nigeria. Mediterrean Journal of Social Sciences, 4(5), 137-146.

[6] Becker, K. 2007. Digital game-based learning once removed: Teaching teachers. British Journal of Educational Technology, 38(3), 478-488.

[7] Schrenko, L.C. 2010. Standards and Guidelines for Work-Based Learning Programmes in Georgia. State of Georgia Department of Education.

[8] Hopkins, E.A. 2008. Work-related learning: Hearing students' voices. Educational Action Research, 16(2), 209-219.

[9] Siregar, S. 2018. A Study of Work Based Learning for Construction Building Workers. Journal of Physics: Conf. Series 970, Doi: 10.1088/1742-6596/970/1/012024

[10] Swallow, V.M., Chalmers, H., Miller, J., Piercy, C., Sen, B. 2001. Accredited work-based learning (AWBL) for new nursing roles: nurses' experiences of two pilot schemes. Journal of Clinical Nursing; 10: 820-821.
[11] Moise, I.A., Popescu, T., Kadar, M., Muntean, M. 2013. Developing students' educational experiences through work-based learning programmes. Procedia - Social and Behavioral Sciences 93, 1045 - 1049

[12] Bolli, T., Hof, S. 2018. The Impact of Work-Based Education on NonCognitive Skills, Journal of Research in Personality, doi: https://doi.org/10.1016/j.jrp.2018.05.005

[13] Eddy, A. 2009. Work-based learning and role extension: A match made in heaven? Radiography, doi: 10.1016/j.radi.2009.12.001

[14] Yan, W., Goubeaud, K., Fry, C. 2004. Does school-to-work matter? Teachers' implementation of school-based and work-based activities. Journal of Career and Technical Education, 21(1), 9-23.

[15] Ugwoke, E.O., Ezeji, H.A., Edeh, N.I., Etonyeaku, E.A.C. 2016. Effective Implementation of TVET-Industry Partnership forEmployability of Graduates through Work Integrated Learning in Nigerian Universities. Review of European Studies, 8(3).

[16] Watisin, W., Ismail, N.I., Hashim, M.H.M. 2015. The problems of bilateral relations between educational institutions and industrial committee towards Work-Based Learning in Malaysia. Procedia-Social and Behavioral Sciences, 172352 - 358.

[17] Fjellström, M. 2014. Vocational education in practice: a study of work-based learning in a construction programme at a Swedish upper secondary school. Empirical Research in Vocational Education and Training, 6:2

[18] Alseddiqi, M., Mishra, R., Pislaru, C. 2010. Design and Development of an OnLineWorkBased Learning (WBL) Module to Enhance the Technical and Vocational Education (TVE) System in Bahrain. In: Global Learn Asia Pacific 2010: Global Conference on Learning and Technology. Association for the Advancement of Computing in Education (AACE), Vancouver, Canada, p. 1168. ISBN 1880094797

[19] Chadd, J., Anderson, M.A. 2005. Illinois work-based learning programs: Worksite mentor knowledge and training. Career and Technical Education Research, 30(1), 25-45.

[20] Nguma, I.A. 2003. Technology education and national development. Retrieved May 13, 2013, fromhttp://www.batchelor.edu.au/public/research.html

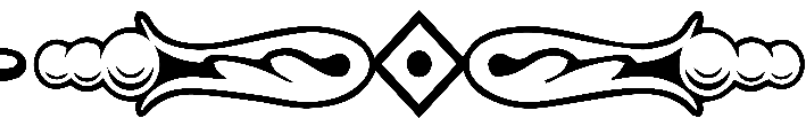

